\title{
Synthesis of homo- and heteromultivalent carbohydrate-functionalized oligo(amidoamines) using novel glyco-building blocks
}

\author{
Felix Wojcik, Sinaida Lel, Alexander G. O'Brien, Peter H. Seeberger* \\ and Laura Hartmann*
}

\section{Full Research Paper}

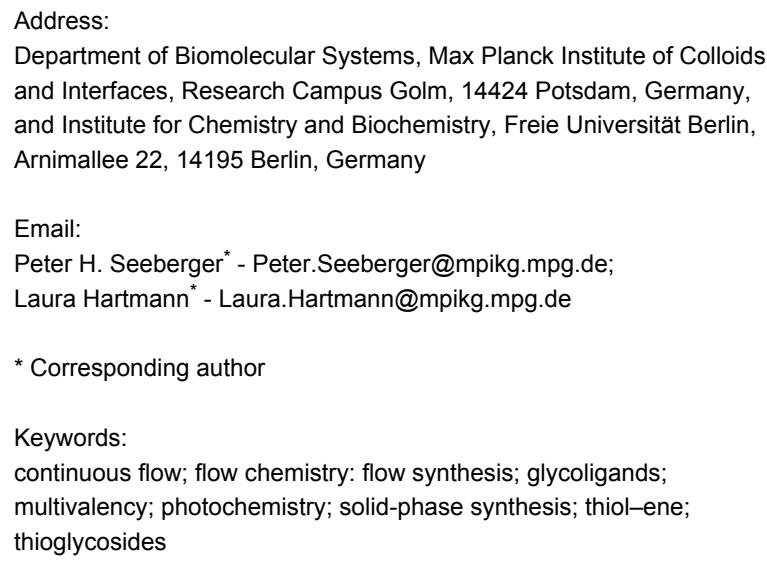

Beilstein J. Org. Chem. 2013, 9, 2395-2403.

doi:10.3762/bjoc. 9.276

Received: 28 June 2013

Accepted: 10 October 2013

Published: 07 November 2013

This article is part of the Thematic Series "Chemistry in flow systems III".

Guest Editor: A. Kirschning

(c) 2013 Wojcik et al; licensee Beilstein-Institut. License and terms: see end of document.

\begin{abstract}
We present the solid phase synthesis of carbohydrate-functionalized oligo(amidoamines) with different functionalization patterns utilizing a novel alphabet of six differently glycosylated building blocks. Highly efficient in flow conjugation of thioglycosides to a double-bond presenting diethylentriamine precursor is the key step to prepare these building blocks suitable for fully automated solid-phase synthesis. Introduction of the sugar ligands via functionalized building blocks rather than postfunctionalization of the oligomeric backbone allows for the straightforward synthesis of multivalent glycoligands with full control over monomer sequence and functionalization pattern. We demonstrate the potential of this building-block approach by synthesizing oligomers with different numbers and spacing of carbohydrates and also show the feasibility of heteromultivalent glycosylation patterns by combining building blocks presenting different mono- and disaccharides.
\end{abstract}

\section{Introduction}

Multivalent carbohydrate ligand-protein receptor interactions play a key role for many events in glycobiology such as cell-cell or pathogen recognition [1]. Therefore, carbohydrate functionalization of non-natural materials such as polymers or dendrimers allows for bioactive materials that are used to modulate cellular behavior [1-3]. Since single carbohydrate ligand-protein interactions are usually weak [4], several sugar ligands have to be introduced in order to achieve the desired biological effect [4]. This multivalent presentation of ligands then results in an increased binding affinity to the targeted 
protein receptors [4]. It is well understood that the number and spacing of ligands have a tremendous influence on the resulting binding and thus biological properties [5-7]. Therefore, in order to understand and explore these interactions and their potential for biomedical applications, a more detailed look at the binding mechanisms as well as structure-activity relationship studies of multivalent glycomaterials is required.

Multivalent sugar presentation has been realized on a variety of different scaffolds such as polymers [8,9], dendrimers [10] or naturally-occurring scaffolds such as peptides [11-13] or oligonucleotides [14]. Such constructs have contributed to our current understanding of multivalent interactions [5]. Nevertheless, binding studies on multivalent compounds with different scaffold architectures or combinations of different sugar ligands are limited due to the often undefined chemical composition, limited variations in architecture and functionalization as well as unspecific biological activity of the scaffolds. Precision oligo/polymers are a novel class of defined artificial scaffolds having the potential to bridge this current gap of artificial carbohydrate presenting scaffolds and to be an important platform for structure-activity relationship studies [15-17]. Precision macromolecules combine the advantages of synthetic scaffolds such as polymers with the advantages of naturally-occurring scaffolds such as peptides as they are highly defined, versatile in their structure (linear or branched) [18] and biocompatible with a decreased risk of inherent immunogenicity [19].

Recently, we showed that monodisperse, sequence-defined glycooligomers obtained by sequential addition of building blocks on solid support are valuable tools for tuning and understanding carbohydrate-lectin interactions [20]. Carbohydrate conjugation was achieved by copper-catalyzed azide alkyne cycloaddtion (CuAAC) of carbohydrate ligands on alkyne presenting oligomers [21]. As an alternative conjugation approach to CuAAc, a very efficient thiol-ene coupling (TEC) [22-25] protocol in a continuous flow photoreactor was developed involving post functionalization of alkene presenting oligomers by thioglycosides [26]. The flow system allows for precise control over the reaction conditions, is easy to scale up and provides efficient irradiation of the samples by virtue of a sub-millimeter path length. Continuous removal of the desired product minimizes unwanted secondary reaction pathways [2739]. We also introduced the so-called building block approach in the context of thiol-ene coupling via the continuous-flow technique. A first example involved conjugating a glucose ligand to a building block and subsequent solid phase assembly of a glycooligomer [26].

When compared to postfunctionalization, the building-block approach allows not only control of the ligand positioning, but also enables well-defined sequences with different types of ligands: Simply by choosing from an alphabet of building blocks, applying them for solid-phase synthesis and final cleavage from the resin, the desired multivalent structures can be obtained. Heteromultivalent glycooligomers presenting different sugars at different positions along the scaffold should be accessible by combining different carbohydrate functionalized building blocks and without the requirement of complex protecting group or sequential functionalization strategies [40]. In order to explore the feasibility of the building-block approach for the synthesis of precision glycooligo/polymers, in this work we report on the reaction of several thioglycosides and the double bond presenting diethylenetriamine succinic acid building block (DDS) 1, giving access to a small alphabet of carbohydrate-functionalized building blocks. TEC in flow enabled determining the reactivity of each thioglycoside at $>275 \mathrm{~nm}$, leading to optimized reaction conditions for the production of six glycosylated building blocks (Figure 1). These building blocks can then be used for the assembly of monodisperse, sequence-defined glycooligomers via fully automated standard amide coupling. Straightforward variations in the scaffold architecture, number and distance of sugar ligands as well as the sequence-defined introduction of different sugars are demonstrated by choosing different building block combinations during solid-phase synthesis.

\section{Results and Discussion}

For the preparation of the desired sugar building blocks doublebond presenting building block DDS 1 and thioglycosides 2-7 are required. The large scale synthesis of DDS 1 was achieved according to a published procedure [26]. The required $\beta$-thioglycosides 2-7 were prepared via their corresponding glycosyl bromides followed by $\mathrm{S}_{\mathrm{N}} 2$ displacement of the anomeric bromide with thiourea [41] or $\mathrm{Na}_{2} \mathrm{~S} / \mathrm{CS}_{2}$ [42].

DDS 1 and thioglycosides 2-7 were subjected to TEC in flow at $>275 \mathrm{~nm}$ (Scheme 1). A FEP flow photoreactor equipped with a Pyrex-filtered medium pressure Hg lamp (400 Watt, $\lambda_{\max }=$ $366 \mathrm{~nm}$ ) cooled to room temperature was employed [43]. Continuous reagent delivery was ensured by a standard commercially available syringe pump (for details see Supporting Information File 1). Reactivity evaluation studies were performed utilizing a $2 \mathrm{~mL}$ FEP loop, for the gram-scale production of glycosylated building blocks a $5 \mathrm{~mL}$ FEP loop was used. This particular photochemical set up (Figure 2a) allows for several reaction parameters to be studied for later high scale synthesis of the glycosylated building blocks 8-13 while using only small amounts of reagents for optimization. As thiol-ene addition is strongly concentration dependent [26], similar concentrations for thioglycosides 2-7 during TEC are required for a valid comparison. Due to reagent solubility, a concentra- 


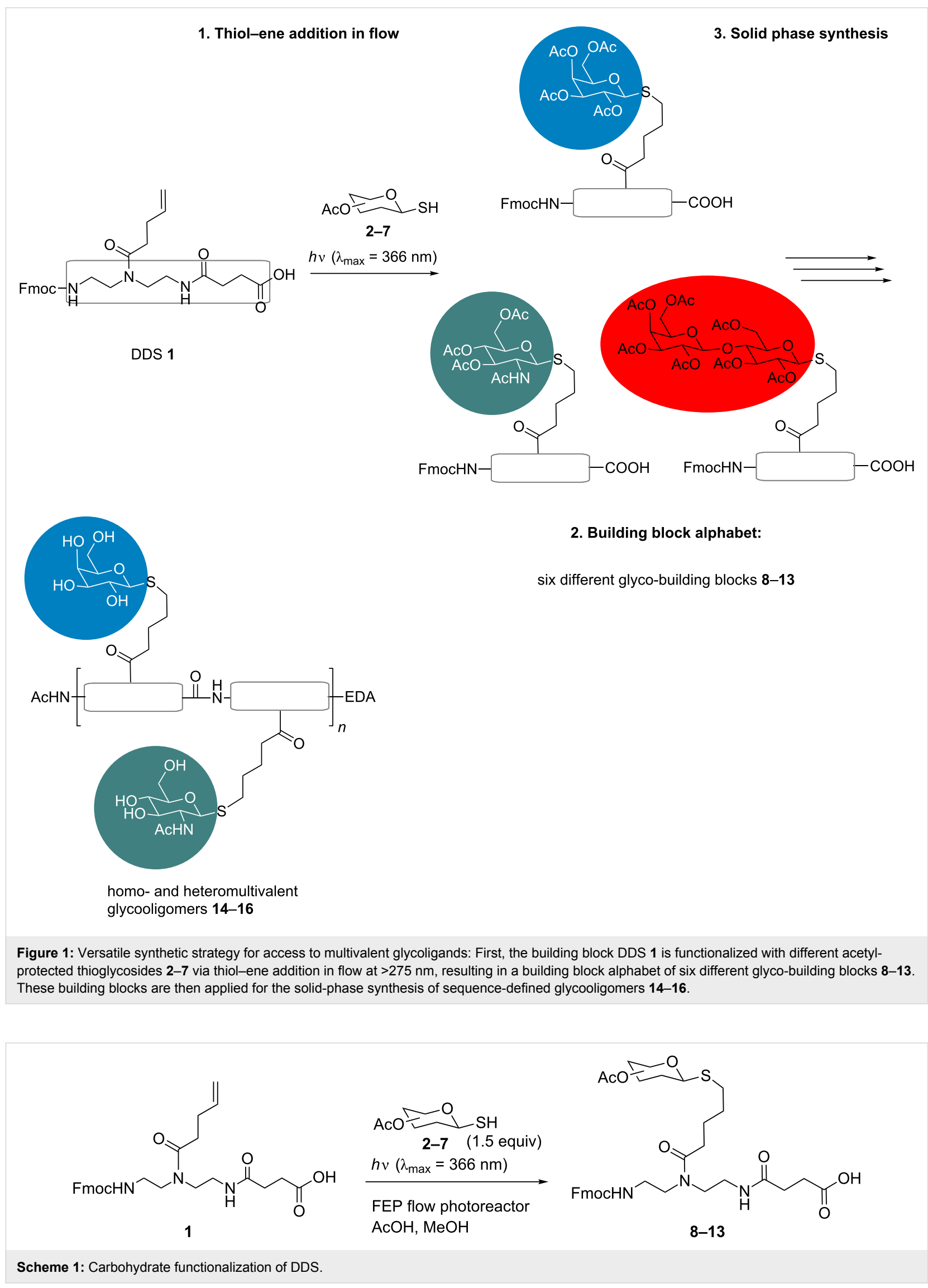


tion of $0.1 \mathrm{M}$ could be only realized by premixing all reagents before injection. In this case it is important to notice that no background reactivity could be measured when performing the reaction without irradiation under similar flow conditions.

a)

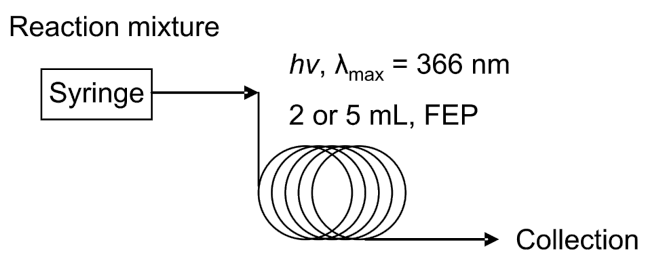

b)

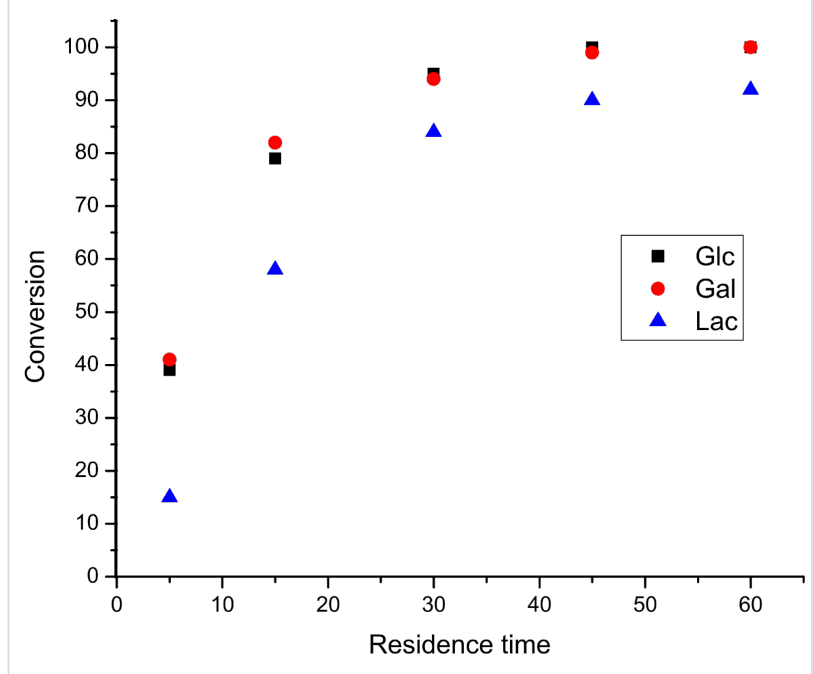

Figure 2: a) Schematic diagram of the TEC photoflow reactor. b) Plot of residence time versus conversion for the addition of the $\beta-\mathrm{Glc}(\mathrm{OAc})_{4}-\mathrm{SH} 2, \beta-\mathrm{Gal}(\mathrm{OAc})_{4}-\mathrm{SH} 3$ and $\beta-\mathrm{Lac}(\mathrm{OAc})_{7}-\mathrm{SH} 7$ to the DDS building block 1 .

Integration of the HPLC UV-signals at $254 \mathrm{~nm}$ was used to establish residence time versus conversion plots (Figure 2). The plots showed close to complete conversion within $30 \mathrm{~min}$ residence time and 1.5 equiv of thioglycoside $\beta$-Glc $(\mathrm{OAc})_{4}-\mathrm{SH} 2$ $(95 \%)$ or $\beta-\mathrm{Gal}(\mathrm{OAc})_{4}-\mathrm{SH} 3$ (94\%) (Figure 2; Glc and Gal) Similar reactivities were also observed for monosaccharides
4-6, supporting the substrate scope of this approach and its suitability to access a library of differently glycosylated building blocks. Referring to larger thio-substrate $\beta$ - Lac(OAc) ${ }_{7}-\mathrm{SH} 7$ a diminished reactivity with the same previously mentioned reaction conditions was determined (Figure 2b; Lac).

With optimized reaction conditions in place, large amounts of glycosylated building blocks are required to support solid phase oligomer synthesis. Large scale production of glycosylated building blocks $8,9,10$ and $\mathbf{1 3}$ relied on the previously established conditions ( $30 \mathrm{~min} ; 1.5$ equiv thioglycoside; $0.1 \mathrm{M}$ ). Although the reactivity of aminoglycosides $\mathbf{5}$ and $\mathbf{6}$ is in the same range as that of glycosides $\mathbf{2 - 4}$, we chose a higher excess of thiol component ( 2 equiv) for the production of glycosylated building blocks 11 and 12, resulting in $>95 \%$ conversion and an easy purification of the reaction mixture. Using this process, gram quantities of glycosylated building blocks 8-13 were obtained in $70-89 \%$ isolated yield after purification (Table 1).

With the isolated and characterized glyco-building blocks 8-13 obtained via TEC in flow, we then assembled three different glycooligomers 14-16 (Figure 3) to show the potential of the building block approach for the straightforward synthesis of a variety of differently glycosylated structures. The oligomer synthesis is based on standard peptide synthesis protocols and amide formation via activation of the building blocks' free carboxy group, coupling to the solid support followed by deprotection of the amino group (Figure 3 ). This allows us to synthesize chemically defined oligomers with full control over the monomer sequence $[15,16,18,26]$ using differently functionalized and spacer building blocks. Due to the use of fully functionalized building blocks the desired product can be obtained directly after cleavage from the resin and after overall deprotection.

In order to be suitable for solid-phase synthesis, the building blocks have to be soluble in DMF or NMP, permanent protective groups have to be stable towards piperidine exposure and the activated species should selectively react with primary amines without prior decomposition. Indeed, all glyco-building blocks described here, fulfil these criteria and can be applied for

\begin{tabular}{|c|c|c|c|c|c|}
\hline Building block & Thiol component & Equiv & Residence time & Conversion & Yield \\
\hline$\beta$-GIcS_DDS 8 & $\beta-\mathrm{Glc}(\mathrm{OAc})_{4}-\mathrm{SH} 2$ & 1.5 & $30 \mathrm{~min}$ & $95 \%$ & $84 \%$ \\
\hline$\beta$-GalS_DDS 9 & $\beta-\mathrm{Gal}(\mathrm{OAc})_{4}-\mathrm{SH} 3$ & 1.5 & $30 \mathrm{~min}$ & $94 \%$ & $81 \%$ \\
\hline$\beta$-RhaS_DDS 10 & $\beta-\mathrm{Rha}(\mathrm{OAc})_{3}-\mathrm{SH} 4$ & 1.5 & $30 \mathrm{~min}$ & $95 \%$ & $89 \%$ \\
\hline$\beta$-GlcNAcS_DDS 11 & $\beta-G I c N A c(O A c)_{3}-S H 5$ & 2 & $30 \mathrm{~min}$ & $>95 \%$ & $81 \%$ \\
\hline$\beta$-GalNAcS_DDS 12 & $\beta$-GalNAc $(\mathrm{OAc})_{3}-\mathrm{SH} 6$ & 2 & $30 \mathrm{~min}$ & $>95 \%$ & $85 \%$ \\
\hline$\beta$-LacS_DDS 13 & $\beta$-Lac $(\mathrm{OAc})_{7}-\mathrm{SH} 7$ & 1.5 & $30 \mathrm{~min}$ & $84 \%$ & $70 \%$ \\
\hline
\end{tabular}




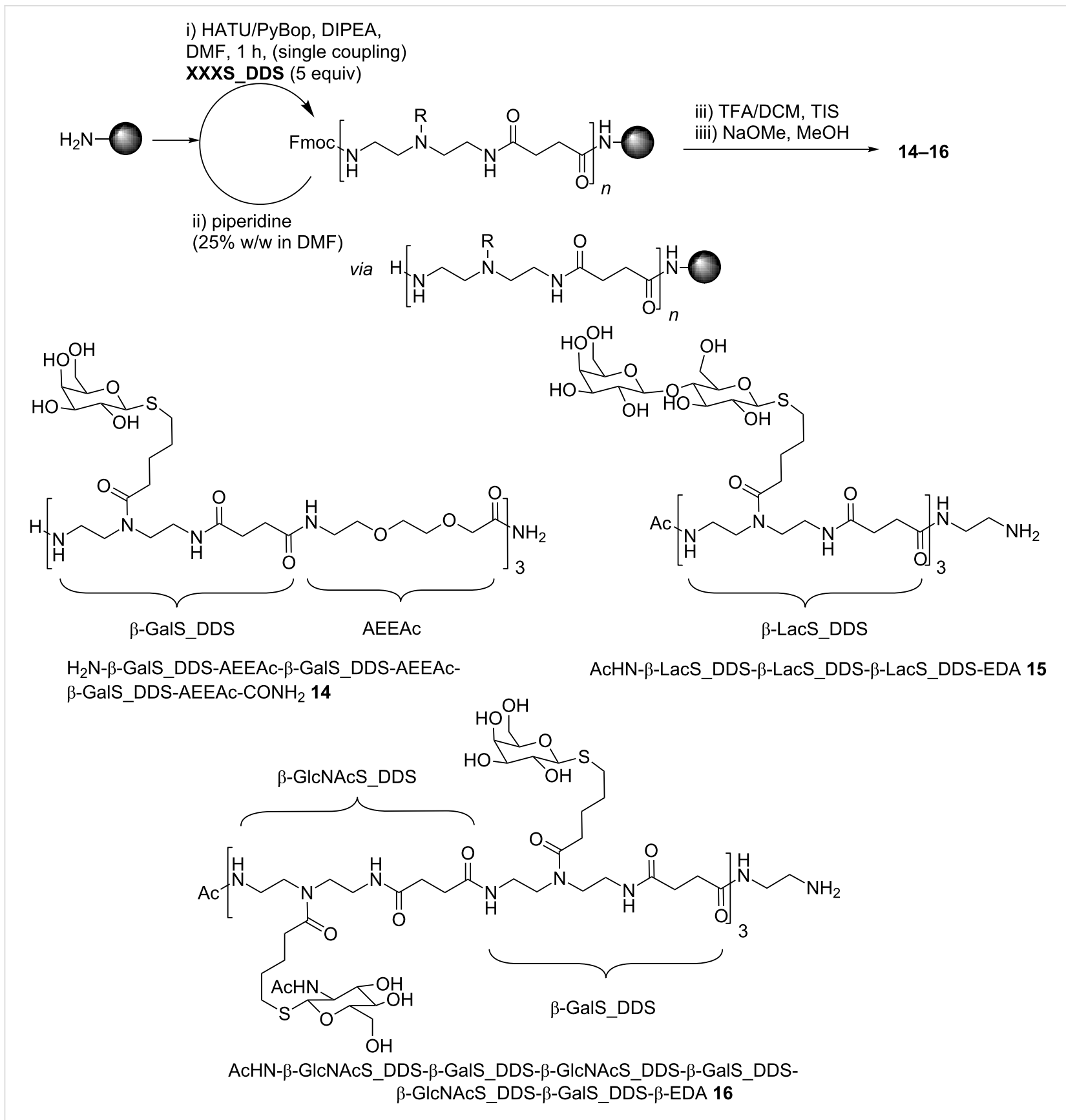

Figure 3: Solid phase coupling procedure and the obtained homo- and heteromultivalent glycoligands 14-16.

sequential coupling under PyBop or HATU activation and Fmoc deprotection with $25 \%$ piperidine in DMF on solid support (Figure 3). Final deprotection from the resin was performed with TFA/DCM mixtures, followed by acetyl deprotection in solution under Zemplén conditions [44]. Although the glycosylated building blocks 9-13 suffer from steric hindrance and have a relatively high molecular weight in comparison to amino acids, they show remarkably good coupling efficiency during amide bond formation on solid support. Glycooligomer 14, combining three $\beta-G a l S \_D D S$ and three amino-diethoxy- acetic acid (AEEAc) building blocks in alternating sequence, was accessible in high yields $(81 \%)$ and purity $(94 \%$ determined via integration of the HPLC signal at $214 \mathrm{~nm}$ ) by referring only to single coupling (5 equiv) for one hour using PyBop activation (see Supporting Information File 1). After diethyl ether precipitation no further purification of compound 14 was necessary. This structure represents an example for a combination of glycosylated and non-glycosylated building blocks that allows for the variation of the density, number and spacing of sugar ligands along the scaffold. In order to test whether the 
building block approach is also suitable for the direct introduction of larger sugar ligands such as the Lac disaccharide, we synthesized structure 15 presenting three Lac ligands placed right next to each other in a short oligomer chain. Indeed, depending on the building blocks applied and oligomer structures targeted, different activating reagents are required. Glycooligomer 15 introducing Lac groups was obtained as highly pure material after solid-phase synthesis using HATU activation instead of PyBop followed by HPLC purification. Another important advantage of the presented building block approach is the straightforward access to so-called heteromultivalent glycooligomers. Here different sugar ligands are presented at different positions along the oligomer chain. To date, such heteromultivalent systems are mainly obtained by functionalization with mixtures of sugar ligands that do not allow for a precise positioning of the different sugar ligands $[9,45]$. Alternatively, a polymer-analogue strategy is required where different functional groups are placed along a polymer chain that allow for orthogonal conjugation strategies introducing the different sugars sequentially $[37,46]$. Our approach simply relies on choosing from our differently glycosylated building blocks that are introduced in the desired pattern by automated solid-phase synthesis. As a proof of principle we synthesized glycoligand $\mathbf{1 6}$ as a multivalent scaffold that presents two different monosaccharides. $\beta$-GlcNAc and $\beta$-Gal are exposed in alternating fashion with an overall oligomer length of six building blocks and a molecular weight of 3000 Da. Similar to glycooligomer 15 this structure was obtained as highly pure material after solid-phase synthesis using HATU activation and HPLC purification.

\section{Conclusion}

In this article we reported on the synthesis of glycosylated building blocks via photochemical thiol-ene chemistry in a continuous-flow reactor using five different monosaccharides and one disaccharide. We showed that this flow set up provides excellent conversion rates with several substrates. All monosaccharides were shown to react under the same conditions with equivalent conversion rates, whereas the peracetylated $\beta$-thiolactose as a disaccharide showed slightly diminished reactivity. Additionally, these small scale reactions were transferred into the gram-scale production of six different glycosylated building blocks.

These carbohydrate presenting building blocks were then applied for solid-phase synthesis resulting in three monodisperse, sequence-defined glycooligomers with different glycosylation patterns. The building-block approach for the synthesis of glycooligomers thus allows for the control of the ligand positioning as well as the straightforward introduction of defined sequences of different types of ligands. Ongoing studies focus on the synthesis of a larger set of different glycooligo/polymers and the evaluation of their binding properties as sugar mimetics. For example, homomultivalent oligomer $\mathbf{1 4}$ and analogues are characterized for their interactions with asialoglycoprotein receptors, while heteromultivalent oligomer 16 represents a potential mimic of poly(lacNAc), which is known to be an important naturally-occurring galectin binder.

\section{Experimental}

General TEC procedure. A photoreactor was set up using $5 \mathrm{~mL}$ (for optimization reactions $2 \mathrm{~mL}$ ) loop of FEP tubing around a Pyrex and a medium pressure Hg lamp [26,43]. A recirculating chiller (Huber Unistat 360, filled with spectroscopically pure water as coolant) was used to maintain the reactor at a temperature of $25-30{ }^{\circ} \mathrm{C}$ (for further details see Supporting Information File 1). Using a syringe pump (Harvard PHD2000), a solution of DDS 1 (1.0 equiv), acetyl-protected thioglycosidesglycoside 2-7 (1.5-2.0 equiv) and acetic acid ( 3 equiv) in degassed methanol was injected into the photoreactor. The entire reactor output was collected and evaporated under reduced pressure to afford the crude material.

及-GIcS_DDS (8): A solution of acetyl protected $\beta$-thioglucose 2 ( $1.35 \mathrm{~g} ; 3.69 \mathrm{mmol}, 1.5$ equiv) and DDS 1 (1.25 g; $2.46 \mathrm{mmol}$, 1.0 equiv) in $\mathrm{MeOH}(24 \mathrm{~mL})$ and $\mathrm{AcOH}(0.42 \mathrm{~mL})$ (residence

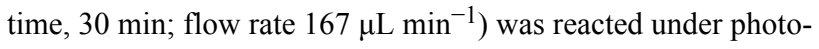
chemical conditions according to the general TEC procedure. The reactor outcome was concentrated and purified via silica chromatography (DCM/MeOH $+1 \% \mathrm{AcOH} 15: 1)$ giving compound 8 (1.8 g; 84\%). The analytical data is in accordance with published data [26].

B-GalS_DDS (9): A solution of acetyl protected $\beta$-thiogalactose 3 (1.35 g; $3.69 \mathrm{mmol}, 1.5$ equiv) and DDS 1 (1.25 g; $2.46 \mathrm{mmol}, 1.0$ equiv) in $\mathrm{MeOH}(24 \mathrm{~mL})$ and $\mathrm{AcOH}(0.42 \mathrm{~mL})$ (residence time, $30 \mathrm{~min}$; flow rate $167 \mu \mathrm{L} \mathrm{m^{-1 }}{ }^{-1}$ was reacted under photochemical conditions according to the general TEC procedure. The reactor outcome was concentrated and purified via silica chromatography (DCM/MeOH $+1 \% \mathrm{AcOH} 15: 1)$ giving compound 9 (1.74 g; 81\%). IR (film) v: 2945, 1748, $1225 \mathrm{~cm}^{-1} ;[\alpha]_{\mathrm{D}}{ }^{20}-32.19$ (c 1, MeOH); ${ }^{1} \mathrm{H}$ NMR (400 MHz, $\left.\mathrm{CDCl}_{3}\right) 7.76(\mathrm{~d}, J=7.5,2 \mathrm{H}), 7.58(\mathrm{~d}, J=7.4,2 \mathrm{H}), 7.39(\mathrm{t}, J=$ $7.4,2 \mathrm{H}), 7.30(\mathrm{t}, J=7.4,2 \mathrm{H}), 7.07-6.83(\mathrm{~m}, 1 \mathrm{H}), 5.86-5.64(\mathrm{~m}$, $1 \mathrm{H}), 5.47-5.35(\mathrm{~m}, 1 \mathrm{H}), 5.19(\mathrm{t}, J=9.8,1 \mathrm{H}), 5.10-4.97(\mathrm{~m}$, $1 \mathrm{H}), 4.65-4.27(\mathrm{~m}, 3 \mathrm{H}), 4.25-3.80(\mathrm{~m}, 4 \mathrm{H}), 3.62-3.18(\mathrm{~m}, 8 \mathrm{H})$, 2.73-2.53 (m, 4H), 2.52-2.29 (m, 4H), $2.12(\mathrm{~s}, 3 \mathrm{H}), 2.05-1.99$ (m, 6H), 1.97 (s, 3H), 1.76-1.50 (m, 4H); ${ }^{13} \mathrm{C}$ NMR (100 MHz, $\mathrm{CDCl}_{3}$ ) (mixture of rotamers) 175.0, 173.1, 172.9, 170.7, 170.4, $170.2,169.9,156.9,143.9,143.9,141.4,141.4,127.9,127.2$, $125.2,125.1,120.2,120.2,84.1,74.5,72.0,67.5,67.5,67.0$, $61.5,48.5,48.3,47.3,45.9,40.1,39.9,39.3,38.6,32.6,32.4$, 
30.9, 29.8, 29.4, 29.4, 29.3, 24.5, 24.5, 20.9, 20.8, 20.8, 20.7; HRMS (ESI) $m / z$ : $[\mathrm{M}+\mathrm{Na}]^{+}$calcd for $\mathrm{C}_{42} \mathrm{H}_{53} \mathrm{~N}_{3} \mathrm{O}_{15} \mathrm{SNa}$, 894.3095; found, 894.3096; RP-HPLC analysis, 5\% to $95 \%$ $\mathrm{MeCN}$ in $10 \mathrm{~min}$, retention time $=8.1 \mathrm{~min}$.

及-RhaS_DDS (10): A solution of acetyl protected L- $\beta$ thiorhamnose 4 (1.13 g; $3.69 \mathrm{mmol}, 1.5$ equiv) and DDS 1 (1.25 g; 2.46 mmol, 1.0 equiv) in $\mathrm{MeOH}(24 \mathrm{~mL})$ and $\mathrm{AcOH}$ $(0.42 \mathrm{~mL})$ (residence time, $30 \mathrm{~min}$; flow rate $167 \mu \mathrm{L} \mathrm{min}{ }^{-1}$ ) was reacted under photochemical conditions according to the general TEC procedure. The reactor outcome was concentrated and purified via silica chromatography (DCM/MeOH $+1 \%$ AcOH 17:1) giving compound 10 (1.78 g; 89\%). IR (film) v: $2940,1745,1630,1224 \mathrm{~cm}^{-1} ;[\alpha]_{\mathrm{D}}{ }^{20}-5.83(c 1, \mathrm{MeOH}) ;{ }^{1} \mathrm{H}$ NMR (400 MHz, $\left.\mathrm{CDCl}_{3}\right) 7.74(\mathrm{~d}, J=7.5,2 \mathrm{H}), 7.57$ (d, $J=7.4$, $2 \mathrm{H}), 7.38(\mathrm{t}, J=7.3,2 \mathrm{H}), 7.29(\mathrm{t}, J=7.6,2 \mathrm{H}), 6.96(\mathrm{br} \mathrm{s}, 1 \mathrm{H})$, $5.86-5.65(\mathrm{~m}, 1 \mathrm{H}), 5.30(\mathrm{dd}, J=3.3,1.5,1 \mathrm{H}), 5.22-5.16(\mathrm{~m}$, $1 \mathrm{H}), 5.14(\mathrm{~s}, 1 \mathrm{H}), 5.07(\mathrm{t}, J=9.8,1 \mathrm{H}), 4.46-4.26(\mathrm{~m}, 2 \mathrm{H})$, 4.24-4.12 (m, 2H), 3.67-3.09 (m, 8H), 2.82-2.23 (m, 8H), 2.17-2.09 (m, 3H), $2.04(\mathrm{~s}, 3 \mathrm{H}), 1.97(\mathrm{~s}, 3 \mathrm{H}), 1.73-1.56(\mathrm{~m}$, $4 \mathrm{H}), 1.19$ (d, J 6.2, 3H); ${ }^{13} \mathrm{C} \mathrm{NMR}\left(100 \mathrm{MHz}, \mathrm{CDCl}_{3}\right)$ (mixture of rotamers) $175.3,175.2,174.9,174.8,173.1,172.9$, $170.4,170.1,170.1,157.3,156.9,143.9,143.9,141.4,141.4$, $127.9,127.2,125.2,125.1,120.1,120.1,82.3,71.8,71.3,69.7$, $67.3,67.0,48.5,48.2,47.3,46.2,45.9,40.1,39.8,39.2,38.6$, $32.6,32.4,31.1,30.8,30.8,29.7,29.4,29.2,29.1,24.5,24.4$, 21.1, 20.9, 20.8, 17.5, 17.5; HRMS (ESI) $m / z:[\mathrm{M}+\mathrm{Na}]^{+}$calcd for $\mathrm{C}_{40} \mathrm{H}_{51} \mathrm{~N}_{3} \mathrm{O}_{13} \mathrm{SNa}$, 836.3040; found, 836.3056; RP-HPLC analysis, $5 \%$ to $95 \% \mathrm{MeCN}$ in $10 \mathrm{~min}$, retention time $=7.8 \mathrm{~min}$.

B-GIcNAcS_DDS (11): A solution of acetyl protected $\beta$-thioglucosamine $\mathbf{5}(0.72 \mathrm{~g} ; 1.97 \mathrm{mmol}, 2.0$ equiv) and DDS 1 $(0.5 \mathrm{~g} ; 0.99 \mathrm{mmol}, 1.0$ equiv) in $\mathrm{MeOH}(10 \mathrm{~mL})$ and $\mathrm{AcOH}$ $\left(0.17 \mathrm{~mL}\right.$ ) (residence time, $30 \mathrm{~min}$; flow rate $167 \mu \mathrm{L} \mathrm{min}^{-1}$ ) was reacted under photochemical conditions according to the general TEC procedure. The reactor outcome was concentrated and purified via silica chromatography (DCM/MeOH + 1\% AcOH 10:1) giving compound 11 (0.70 g; 81\%). IR (film) v: 2940, 1744, 1654, $1229 \mathrm{~cm}^{-1} ;[\alpha]_{\mathrm{D}}{ }^{20}+25.65(c 2, \mathrm{MeOH}) ;{ }^{1} \mathrm{H}$ NMR (400 MHz, $\left.\mathrm{CDCl}_{3}\right)$ 7.77-7.71 (m, 2H), 7.57 (d, $J=7.3$, $2 \mathrm{H}), 7.37(\mathrm{t}, J=7.4,2 \mathrm{H}), 7.33-7.25(\mathrm{~m}, 2 \mathrm{H}), 5.21-4.99(\mathrm{~m}$, $2 \mathrm{H}), 4.64-4.50(\mathrm{~m}, 1 \mathrm{H}), 4.41-3.99(\mathrm{~m}, 6 \mathrm{H}), 3.72-3.56(\mathrm{~m}, 1 \mathrm{H})$, $3.51-3.17(\mathrm{~m}, 8 \mathrm{H}), 2.76-2.52(\mathrm{~m}, 4 \mathrm{H}), 2.50-2.28(\mathrm{~m}, 4 \mathrm{H}), 2.02$ (s, 3H), 2.00-1.95 (m, 6H), 1.89 (d, $J=9.1 \mathrm{~Hz}, 2 \mathrm{H}), 1.75-1.42$ $(\mathrm{m}, 2 \mathrm{H}) ;{ }^{13} \mathrm{C}$ NMR $\left(100 \mathrm{MHz}, \mathrm{CDCl}_{3}\right)$ (mixture of rotamers) $174.8,174.7,173.2,171.2,171.2,171.1,170.1,169.5,169.5$, $157.2,157.0,143.8,141.3,127.9,127.2,125.1,120.1,83.7$, $83.7,75.7,74.1,68.6,68.6,67.0,66.9,62.4,53.0,53.0,48.2$, $47.9,47.2,46.1,45.8,39.7,38.5,38.3,32.3,32.1,30.9,29.8$, 29.3, 29.3, 28.3, 23.9, 23.8, 23.1, 20.9, 20.8, 20.7; HRMS (ESI) $m / z:[\mathrm{M}+\mathrm{Na}]^{+}$calcd for $\mathrm{C}_{42} \mathrm{H}_{54} \mathrm{~N}_{4} \mathrm{O}_{14} \mathrm{SNa}, 893.3255$; found,
893.3263; RP-HPLC analysis, $5 \%$ to $95 \% \mathrm{MeCN}$ in $10 \mathrm{~min}$, retention time $=7.1 \mathrm{~min}$.

及-GalNAcS_DDS (12): A solution of acetyl protected $\beta$-thiogalactosamine 6 (0.72 g; $1.97 \mathrm{mmol}, 2.0$ equiv) and DDS 1 (0.5 g; 0.99 mmol, 1.0 equiv) in $\mathrm{MeOH}(10 \mathrm{~mL})$ and $\mathrm{AcOH}$

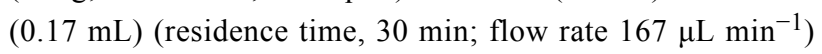
was reacted under photochemical conditions according to the general TEC procedure. The reactor outcome was concentrated and purified via silica chromatography (DCM/MeOH $+1 \%$ AcOH 10:1) giving compound 12 (0.73 g; 85\%). IR (film) v: $1746,1655,1236 \mathrm{~cm}^{-1} ;[\alpha]_{\mathrm{D}}{ }^{20}+145.42(c 2, \mathrm{MeOH}) ;{ }^{1} \mathrm{H}$ NMR $\left(400 \mathrm{MHz}, \mathrm{CDCl}_{3}\right) 7.77-7.69(\mathrm{~m}, 2 \mathrm{H}), 7.56(\mathrm{~d}, J=7.3,2 \mathrm{H})$, $7.36(\mathrm{t}, J=7.4,2 \mathrm{H}), 7.32-7.23(\mathrm{~m}, 2 \mathrm{H}), 5.39-5.25(\mathrm{~m}, 1 \mathrm{H})$, $5.14-5.01(\mathrm{~m}, 1 \mathrm{H}), 4.57(\mathrm{t}, J=10.5,1 \mathrm{H}), 4.41-3.94(\mathrm{~m}, 6 \mathrm{H})$, 3.90-3.77 (m, 1H), 3.54-3.04 (m, 8H), 2.78-2.52 (m, 4H), $2.51-2.27(\mathrm{~m}, 4 \mathrm{H}), 2.10(\mathrm{~s}, 3 \mathrm{H}), 2.05-1.84(\mathrm{~m}, 9 \mathrm{H}), 1.79-1.45$ $(\mathrm{m}, 4 \mathrm{H}) ;{ }^{13} \mathrm{C}$ NMR $\left(100 \mathrm{MHz}, \mathrm{CDCl}_{3}\right)$ (mixture of rotamers) $175.2,174.8,174.7,173.1,173.0,171.5,171.3,170.8,170.7$, $170.5,170.5,157.2,143.8,143.8,141.3,128.0,127.2,125.2$, $125.1,120.1,84.2,84.0,74.3,71.7,71.6,67.0,66.9,61.8,61.8$, $49.2,48.2,47.8,47.3,46.2,45.8,39.7,38.5,38.4,32.3,32.1$, $30.7,30.6,29.7,29.6,29.4,28.4,28.3,23.9,23.8,23.2,23.2$, 20.8, 20.7; HRMS (ESI) $\mathrm{m} / \mathrm{z}:[\mathrm{M}+\mathrm{Na}]^{+}$calcd for $\mathrm{C}_{42} \mathrm{H}_{54} \mathrm{~N}_{4} \mathrm{O}_{14} \mathrm{SNa}$, 893.3255; found, 893.3247; RP-HPLC analysis, $5 \%$ to $95 \% \mathrm{MeCN}$ in $10 \mathrm{~min}$, retention time $=7.1 \mathrm{~min}$.

ק-LacS_DDS (13): A solution of acetyl protected $\beta$-thiolactose 7 (0.79 g; $1.18 \mathrm{mmol}, 1.5$ equiv) and DDS 1 (0.4 g; $0.79 \mathrm{mmol}$, 1.0 equiv) in $\mathrm{MeOH}(7.9 \mathrm{~mL})$ and $\mathrm{AcOH}(0.17 \mathrm{~mL})$ (residence

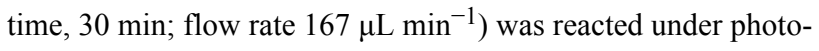
chemical conditions according to the general TEC procedure. The reactor outcome was concentrated and purified via silica chromatography (DCM/MeOH $+1 \% \mathrm{AcOH} 15: 1)$ giving compound $13(0.65 \mathrm{~g} ; 70 \%)$. IR (film) v: $1750,1230,1051 \mathrm{~cm}^{-1}$; $[\alpha]_{\mathrm{D}}{ }^{20}-35.00(c 2, \mathrm{MeOH}) ;{ }^{1} \mathrm{H}$ NMR $\left(400 \mathrm{MHz}, \mathrm{CDCl}_{3}\right) 7.72$ $(\mathrm{d}, J=7.5,2 \mathrm{H}), 7.55(\mathrm{~d}, J=7.5,2 \mathrm{H}), 7.37(\mathrm{t}, J=7.3,2 \mathrm{H})$, $7.29-7.25(\mathrm{~m}, 2 \mathrm{H}), 5.31(\mathrm{~s}, 1 \mathrm{H}), 5.16(\mathrm{dt}, J=9.2,3.1,1 \mathrm{H}), 5.06$ $(\mathrm{t}, J=7.9,1 \mathrm{H}), 4.96-4.85(\mathrm{~m}, 2 \mathrm{H}), 4.47-4.04(\mathrm{~m}, 9 \mathrm{H})$, $3.87-3.71(\mathrm{~m}, 2 \mathrm{H}), 3.55(\mathrm{br} \mathrm{s}, 1 \mathrm{H}), 3.45-3.29(\mathrm{~m}, 8 \mathrm{H})$, 2.63-2.54 (m, 4H), 2.44-2.29 (m, 2H), 2.34-2.27 (m, 2H); 2.11 (s, 3H), 2.06-2.05 (m, 3H), 2.02-1.98 (m, 12H), $1.93(\mathrm{~s}, 3 \mathrm{H})$, $1.67-1.52(\mathrm{~m}, 4 \mathrm{H}) ;{ }^{13} \mathrm{C} \mathrm{NMR}\left(100 \mathrm{MHz}, \mathrm{CDCl}_{3}\right)$ (mixture of rotamers) $174.9,174.7,172.8,172.7,170.6,170.5,170.3$, $170.3,170.1,170.0,169.8,169.8,169.7,169.7,169.6,169.1$, $169.1,157.0,156.7,143.8,143.7,141.3,141.2,127.8,127.7$, $127.1,125.0,125.0,120.0,120.0,101.0,83.2,76.1,73.8,70.9$, $70.6,70.3,69.1,66.9,66.8,66.6,62.2,62.1,60.8,60.8,48.3$, 47.9, 47.1, 46.00, 45.6, 39.9, 38.9, 38.4, 32.4, 32.2, 30.7, 29.7, 29.6, 29.5, 29.2, 29.1, 24.2, 20.8, 20.7, 20.7, 20.6, 20.4; HRMS (ESI) $m / z:[\mathrm{M}+\mathrm{Na}]^{+}$calcd for $\mathrm{C}_{54} \mathrm{H}_{69} \mathrm{~N}_{3} \mathrm{O}_{23} \mathrm{SNa}, 1182.3940$; 
found, 1182.3956; RP-HPLC analysis, $5 \%$ to $95 \% \mathrm{MeCN}$ in $10 \mathrm{~min}$, retention time $=9.3 \mathrm{~min}$.

$\mathrm{H}_{2} \mathrm{~N}$ - $\boldsymbol{\beta}$-GalS_DDS-AEEAc- $\beta$-GaIS_DDS-AEEAc$\boldsymbol{\beta}$-GalS_DDS-AEEAc-CONH 2 (14): Compound 14 (30 mg, $16.2 \mu \mathrm{mol})$ was obtained as white hygroscopic powder after cleavage from the resin, precipitation into diethyl ether and deactylation with a yield of $81 \%$. MALDI-TOF-MS: [M + $\mathrm{Na}]^{+}$calcd for $\mathrm{C}_{75} \mathrm{H}_{135} \mathrm{~N}_{13} \mathrm{O}_{33} \mathrm{~S}_{3} \mathrm{Na}, 1864.83$ (monoisotopic); found, 1864.63 ; RP-HPLC analysis $5 \%$ to $95 \% \mathrm{MeCN}$ in $10 \mathrm{~min}$, retention time $=3.9 \mathrm{~min}$.

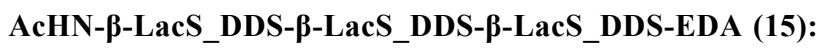
Acetyl protected compound $\mathbf{1 5}$ was cleaved from the resin and precipitated into diethyl ether. The crude material was purified via preparative RP-HPLC ( 5 to $95 \% \mathrm{MeCN}$ in $30 \mathrm{~min}$ ) and freezed-dried. After final deactylation compound $\mathbf{1 5}(11 \mathrm{mg}$, $5.6 \mu \mathrm{mol}$ ) was obtained as white hygroscopic powder with $28 \%$ yield. MALDI-TOF-MS: $[\mathrm{M}+\mathrm{H}]^{+}$calcd for $\mathrm{C}_{79} \mathrm{H}_{140} \mathrm{~N}_{11} \mathrm{O}_{4} 0 \mathrm{~S}_{3}, 1978.84$ (monoisotopic); found, 1979.06; $[\mathrm{M}+\mathrm{Na}]^{+}$calcd for $\mathrm{C}_{79} \mathrm{H}_{139} \mathrm{~N}_{11} \mathrm{O}_{4} 0 \mathrm{~S}_{3} \mathrm{Na}, 2000.82$ (monoisotopic); found, 2000.88; $[\mathrm{M}+\mathrm{K}]^{+}$calcd for $\mathrm{C}_{79} \mathrm{H}_{139} \mathrm{~N}_{11} \mathrm{O}_{4} 0 \mathrm{~S}_{3} \mathrm{~K}$, 2016.80 (monoisotopic); found, 2017.01; RP-HPLC analysis $5 \%$ to $50 \% \mathrm{MeCN}$ in $30 \mathrm{~min}$, retention time $=5.9 \mathrm{~min}$.

AcHN- $\beta-G I c N A c S \_D D S-\beta-G a I S \_D D S-\beta-G I c N A c S \_D D S-\beta-$ GalS_DDS- $\beta$-GIcNAcS_DDS- $\beta$-GaIS_DDS- $\beta$-EDA (16)

Acetyl protected compound $\mathbf{1 6}$ was cleaved from the resin and precipitated into diethyl ether. After deactylation in solution, the crude material was purified via preparative RP-HPLC (5 to 50\% $\mathrm{MeCN}$ in $30 \mathrm{~min}$ ) and freezed-dried. Compound $\mathbf{1 6}(12.6 \mathrm{mg}$, $4.2 \mu \mathrm{mol})$ was obtained as white hygroscopic powder with $21 \%$ yield. MALDI-TOF-MS: $[\mathrm{M}+\mathrm{Na}]^{+}$calcd for $\mathrm{C}_{124} \mathrm{H}_{217} \mathrm{~N}_{23} \mathrm{O}_{49} \mathrm{~S}_{6} \mathrm{Na}, 3027.34$ (monoisotopic); found, 3027.71; RP-HPLC analysis $5 \%$ to $50 \% \mathrm{MeCN}$ in $30 \mathrm{~min}$, retention time $=7.8 \mathrm{~min}$.

\section{Supporting Information}

\section{Supporting Information File 1}

Further experimental procedures, characterization data and spectra.

[http://www.beilstein-journals.org/bjoc/content/ supplementary/1860-5397-9-276-S1.pdf]

\section{Acknowledgements}

The authors thank the Max Planck Society as well as the German Research Foundation (DFG, Emmy Noether program HA5950/1-1) for financial support and Prof. Tyler McQuade and Dr. Kerry Gilmore for helpful discussions.

\section{References}

1. Bertozzi, C. R.; Kiessling, L. L. Science 2001, 291, 2357-2364. doi:10.1126/science. 1059820

2. Kiessling, L. L.; Gestwicki, J. E.; Strong, L. E. Angew. Chem., Int. Ed. 2006, 45, 2348-2368. doi:10.1002/anie.200502794

3. Krannig, K.-S.; Schlaad, H. J. Am. Chem. Soc. 2012, 134, 18542-18545. doi:10.1021/ja308772d

4. Fasting, C.; Schalley, C. A.; Weber, M.; Seitz, O.; Hecht, S.; Koksch, B.; Dernedde, J.; Graf, C.; Knapp, E. W.; Haag, R. Angew. Chem., Int. Ed. 2012, 51, 10472-10498. doi:10.1002/anie.201201114

5. Jayaraman, N. Chem. Soc. Rev. 2009, 38, 3463-3483. doi:10.1039/b815961k

6. Pieters, R. J. Org. Biomol. Chem. 2009, 7, 2013-2025. doi:10.1039/b901828j

7. Lindhorst, T. K. Top. Curr. Chem. 2002, 218, 201-235. doi:10.1007/3-540-45010-6_7

8. Kiessling, L. L.; Gestwicki, J. E.; Strong, L. E. Curr. Opin. Chem. Biol. 2000, 4, 696-703. doi:10.1016/S1367-5931(00)00153-8

9. Becer, C. R.; Gibson, M. I.; Geng, J.; llyas, R.; Wallis, R.; Mitchell, D. A.; Haddleton, D. M. J. Am. Chem. Soc. 2010, 132, 15130-15132. doi:10.1021/ja1056714

10. Cloninger, M. J. Curr. Opin. Chem. Biol. 2002, 6, 742-748. doi:10.1016/S1367-5931(02)00400-3

11. Wittmann, V.; Seeberger, S. Angew. Chem., Int. Ed. 2000, 39 , $4348-4352$. doi:10.1002/1521-3773(20001201)39:23<4348::AID-ANIE4348>3.0.CO ;2-X

12. Galan, M. C.; Dumy, P.; Renaudet, O. Chem. Soc. Rev. 2013, 42, 4599-4612. doi:10.1039/c2cs35413f

13. Jeon, I.; Lee, D.; Krauss, I. J.; Danishefsky, S. J. J. Am. Chem. Soc. 2009, 131, 14337-14344. doi:10.1021/ja9052625

14. Schlegel, M. K.; Hutter, J.; Eriksson, M.; Lepenies, B.; Seeberger, P. H. ChemBioChem 2011, 12, 2791-2800. doi:10.1002/cbic.201100511

15. Hartmann, L. Macromol. Chem. Phys. 2011, 212, 8-13. doi:10.1002/macp.201000479

16. Hartmann, L.; Borner, H. G. Adv. Mater. 2009, 21, 3425-3431. doi:10.1002/adma.200801884

17. Mosca, S.; Wojcik, F.; Hartmann, L. Macromol. Rapid Commun. 2011, 32, 197-202. doi:10.1002/marc.201000593

18. Wojcik, F.; Mosca, S.; Hartmann, L. J. Org. Chem. 2012, 77, 4226-4234. doi:10.1021/jo202561k

19. Chabre, Y. M.; Roy, R. Curr. Top. Med. Chem. 2008, 8, 1237-1285. doi:10.2174/156802608785848987

20. Ponader, D.; Wojcik, F.; Beceren-Braun, F.; Dernedde, J.; Hartmann, L. Biomacromolecules 2012, 13, 1845-1852. doi:10.1021/bm300331z

21. Hoyle, C. E.; Bowman, C. N. Angew. Chem., Int. Ed. 2010, 49 , 1540-1573. doi:10.1002/anie.200903924

22. Dondoni, A.; Marra, A. Chem. Soc. Rev. 2012, 41, 573-586. doi:10.1039/c1cs15157f

23. Griesbaum, K. Angew. Chem., Int. Ed. Engl. 1970, 9, 273-287. doi:10.1002/anie.197002731

24. Dondoni, A. Angew. Chem., Int. Ed. 2008, 47, 8995-8997. doi:10.1002/anie.200802516

25. Northrop, B. H.; Coffey, R. N. J. Am. Chem. Soc. 2012, 134, 13804-13817. doi:10.1021/ja305441d

26. Wojcik, F.; O'Brien, A. G.; Götze, S.; Seeberger, P. H.; Hartmann, L. Chem.-Eur. J. 2013, 19, 3090-3098. doi:10.1002/chem.201203927 
27. Suzuki, Y.; Laurino, P.; McQuade, D. T.; Seeberger, P. H. Helv. Chim. Acta 2012, 95, 2578-2588. doi:10.1002/hlca.201200487

28. Bou-Hamdan, F. R.; Levesque, F.; O'Brien, A. G.; Seeberger, P. H. Beilstein J. Org. Chem. 2011, 7, 1124-1129. doi:10.3762/bjoc.7.129

29. O'Brien, A. G.; Horváth, Z.; Lévesque, F.; Lee, J. W.; Seidel-Morgenstern, A.; Seeberger, P. H. Angew. Chem., Int. Ed. 2012, 51, 7028-7030. doi:10.1002/anie.201202795

30. Bogdan, A. R.; Poe, S. L.; Kubis, D. C.; Broadwater, S. J.; McQuade, D. T. Angew. Chem., Int. Ed. 2009, 48, 8547-8550. doi:10.1002/anie.200903055

31. Lévesque, F.; Seeberger, P. H. Angew. Chem., Int. Ed. 2012, 51, 1706-1709. doi:10.1002/anie.201107446

32. Mason, B. P.; Price, K. E.; Steinbacher, J. L.; Bogdan, A. R.; McQuade, D. T. Chem. Rev. 2007, 107, 2300-2318. doi:10.1021/cr050944c

33. Andrews, R. S.; Becker, J. J.; Gagné, M. R. Angew. Chem., Int. Ed. 2012, 51, 4140-4143. doi:10.1002/anie.201200593

34. Bou-Hamdan, F. R.; Seeberger, P. H. Chem. Sci. 2012, 3, 1612-1616. doi:10.1039/c2sc01016j

35. Knowles, J. P.; Elliott, L. D.; Booker-Milburn, K. I. Beilstein J. Org. Chem. 2012, 8, 2025-2052. doi:10.3762/bjoc.8.229

36. Noël, T.; Buchwald, S. L. Chem. Soc. Rev. 2011, 40, 5010. doi:10.1039/c1cs15075h

37. Booker-Milburn, K. Nat. Chem. 2012, 4, 433-435. doi:10.1038/nchem.1356

38. Gutierrez, A. C.; Jamison, T. F. Org. Lett. 2011, 13, 6414-6417. doi:10.1021/ol2027015

39. Wegner, J.; Ceylan, S.; Kirschning, A. Adv. Synth. Catal. 2012, 354, 17-57. doi:10.1002/adsc.201100584

40. Baradel, N.; Fort, S.; Halila, S.; Badi, N.; Lutz, J. F. Angew. Chem., Int. Ed. 2013, 52, 2335-2339. doi:10.1002/anie.201209052

41. Floyd, N.; Vijayakrishnan, B.; Koeppe, A. R.; Davis, B. G. Angew. Chem., Int. Ed. 2009, 48, 7798-7802. doi:10.1002/anie.200903135

42. Jana, M.; Misra, A. K. J. Org. Chem. 2013, 78, 2680-2686. doi:10.1021/jo302115k

43. Hook, B. D. A.; Dohle, W.; Hirst, P. R.; Pickworth, M.; Berry, M. B.; Booker-Milburn, K. I. J. Org. Chem. 2005, 70, 7558-7564. doi:10.1021/jo050705p

44. Wang, Z. In Comprehensive Organic Name Reactions and Reagents; John Wiley \& Sons, Inc.: 2009, p 3123-3128. doi:10.1002/9780470638859

45. Gestwicki, J. E.; Cairo, C. W.; Strong, L. E.; Oetjen, K. A.; Kiessling, L. L. J. Am. Chem. Soc. 2002, 124, 14922-14933. doi:10.1021/ja027184x

46. Lutz, J. F. Angew. Chem., Int. Ed. 2007, 46, 1018-1025. doi:10.1002/anie.200604050

\section{License and Terms}

This is an Open Access article under the terms of the Creative Commons Attribution License

(http://creativecommons.org/licenses/by/2.0), which permits unrestricted use, distribution, and reproduction in any medium, provided the original work is properly cited.

The license is subject to the Beilstein Journal of Organic Chemistry terms and conditions:

(http://www.beilstein-journals.org/bjoc)

The definitive version of this article is the electronic one which can be found at:

doi:10.3762/bjoc.9.276 